\title{
The Utilization of Moodle-Based Learning Management System (LMS) in Learning Mathematics and Physics to Students' Cognitive Learning Outcomes
}

\author{
Nuraini Fatmi ${ }^{1, a}$ Iryana Muhammad ${ }^{1, b *}$ Muliana $^{1, c}$ \& Sayni Nasrah ${ }^{1, d}$ \\ 1Universitas Malikussaleh, Aceh Utara, Indonesia

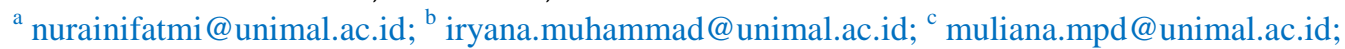 \\ d sayni.nasrah@unimal.ac.id \\ *Corresponding Author: iryanamuhammad@unimal.ac.id | Phone Number: +6285262807674
}

\begin{abstract}
This study aims to determined whether there was an increase in student cognitive learning outcomes through the use of a Moodle-based Learning Management System in mathematics and physics learning. This type of research uses a pre experimental design. The population in this study were students of Babussalam SMKS, while the sample was class XI students of the Babussalam North Aceh Islamic Boarding School. Based on the results of the analysis and discussion of research data, The percentage of the number of students who met the completeness criteria in the physics class was $67 \%$ while in the mathematics class it was $91 \%$. The average $\mathrm{N}$-gain of cognitive learning outcomes for mathematics class was 0.6, higher than the N-gain average for Physics subjects, 0.475 . This is because physics learning is not sufficiently taught through the delivery of material through Moodle, but must involve students in learning with a scientific approach. In this study, Moodle has not optimally integrated learning activities with a scientific approach so that cognitive learning outcomes have not reached the expected targets in physics subjects and learning is not sufficiently taught through the delivery of material through Moodle, but must involve students in learning with a scientific approach. In this study, Moodle has not optimally integrated learning activities with a scientific approach so that cognitive learning outcomes have not reached the expected targets in physics subjects.. In this study, Moodle has not optimally integrated learning activities with a scientific approach so that cognitive learning outcomes have not reached the expected targets in physics subjects.
\end{abstract}

Keywords: Learning Management System (LMS); Moodle; Mathematics; Physics; Cognitive Learning Outcomes;

\section{Introduction}

The Covid-19 pandemic that hit the world at the end of 2019 not only had an impact on the world economy but also on the world of education. In Indonesia in general and Aceh in particular starting from March 16, 2020 teaching and learning activities in schools were stopped. Schools are deserted from the hustle and bustle of education as it usually seems. This condition requires education practitioners to find solutions so that learning must be able to take place even if it is a long distance. Distance learning is a solution that is offered to keep the teaching and learning process carried out. The use of internet facilities is a solution that can be done for now that can overcome the distance and space between teachers and students. However, in practice the use of the internet is not sufficient. Teachers must be more able to creative the learning process online (Karlina, 2015). Although basically the use of the internet in the online learning process must be done in learning in the era of the industrial revolution 4.0 (Rohida, 2018).

Online learning based on several international research results still needs attention, especially on access to education in rural and remote areas in the form of adequate facilities and access to education, especially in rural areas including financial assistance, especially for the poor who have difficulty accessing the internet (Febrianto, 2020). In addition, there are various problems in the implementation of online learning, namely the limitations in the presentation of material, especially in material that involves mathematical equations and programming due to the limited ability of educators to utilize multimedia learning (Irfan et al, 2020). So based on this research, universities must implement a platform that supports online learning activities so that it makes it easier for educators to present material, especially on learning that prioritizes mathematical and scientific aspects and delves further into the obstacles faced by students in online learning. As for 
students' perceptions of online learning, online learning is considered less effective and not in accordance with expectations because online learning does not have thorough preparation from teachers and institutions, namely material readiness, and material transfer methods in order to improve student knowledge, attitudes and skills (Syauqi et al, 2020).

Several previous studies, Albariki et al (2020), Abda et al (2020), Kusuma \& Hamidah (2021), Mada \& Anharuddin (2019), Marhami et al (2020), Mauliza (2020), and Nurulwati et al (2020) found that online learning was able to significantly increase students' learning independence. Video conferencing helps students in solving contextual problems, and is able to build student confidence. Not only that, cognitive abilities also improved significantly. However, teachers need to provide students with comprehensive instructions for using online learning.

The results of the above research are the background for conducting a survey in the form of interviews conducted on several teachers and students at the SMKS level which obtained results in the form of information, namely the teacher also feels overwhelmed and heavy in preparing teaching materials, especially for exact subjects such as mathematics and physics. The presentation of material that has been carried out by the teacher so far is through the WhatsApp media, Microsoft team, and other online learning media but is more implemented textually due to internet network barriers among students. In addition, students also stated that it was difficult to understand the material in these subjects due to the limited duration of material delivery and the difficulty of carrying out question and answer activities if there was material that was difficult to understand. This distance learning not only has an impact on student learning outcomes but also on students' interest in learning because they have difficulty understanding the material so they have started to dislike mathematics and physics. Therefore, this condition cannot continue. There must be the best solution to overcome these problems, because the ineffectiveness of learning will have an impact on the quality of education. One alternative that teachers can do in preparing and designing learning is to use the Moodle-based Learning Management System. because the ineffectiveness of learning will have an impact on the quality of education. One alternative that teachers can do in preparing and designing learning is to use the Moodle-based Learning Management System. because the ineffectiveness of learning will have an impact on the quality of education. One alternative that teachers can do in preparing and designing learning is to use the Moodle-based Learning Management System.

Basically, Moodle is a learning media, namely a tool that helps the implementation of the teaching and learning process (Gunawan, 2015). Moodle is a software application that can help plan, implement a learning process. The use of Moodle in learning can improve student learning outcomes has been proven by Ariesta et al (2019) that the use of Moodle in learning energy material in supporting the use of e-learning is proven to improve student learning outcomes and motivation so learning with Moodle is highly recommended because it is considered effective. . In addition, the creativity of prospective teachers increases every semester which shows that there is a pattern of improvement in the ability of teachers to design Moodle used in learning (Gunawan et al, (2019).

The use of Moodle can build systems with the concept of E-Learning (electronic learning) or Distance Learning (distance learning). Various forms of learning material can be included in this Moodle application. Various sources (resources) can be attached as learning materials. Below are some of the lessons Moodle supports: Assignments, chat, forums, quizzes, surveys. Moodle also provides the convenience of changing the appearance model (themes) of e-learning websites by using template techniques. The strengths of Moodle are: (1) The network system and its security can be set by yourself; (2) The access space that can be limited according to the network created; (3) a learning system that can be tailored to the needs (because it is open source); (4) Complete features for a distance learning process.

\section{Materials and Methods}

This study uses a quantitative research approach with experimental methods. Sukmadinata (2020) argues that experimental research is the most complete quantitative research approach, in the sense that it fulfills all the requirements for testing causal relationships. This type of research used pre-experimental designs. This research was conducted at the Babussalam SMKS Islamic Boarding School, Jl. Medan - Banda Aceh, Alue Bili Rayeuk, Baktiya, North Aceh District. The sample in this study were students of class XI Babussalam SMKS.

This research begins with a survey (data collection) about the conditions of online learning at Babulussalam SMKS. This school was chosen because of the location and availability of adequate internet facilities. In addition, SMKS Babussalam is an SMKS that has implemented the 2013 curriculum and is an integrated school, because it combines general education and religious education in one curriculum. So that all subjects taught cannot be separated from the frame of religious teachings and religious lessons are enriched with the approach of the context of the times, benefits and benefits. This condition is considered to 
be interesting, especially in finding problems that arise from the process of implementing online learning.

After making preliminary observations to find problems, a literacy study was carried out about solutions to problems that resulted in hypotheses to utilize the Moodle based Learning Management System (LMS) in an effort to improve student cognitive learning outcomes. Therefore, as a further step, the Moodle design is carried out which will be used as a solution in overcoming learning problems and the development of research instruments to measure student learning outcomes before and after learning with Moodle. Moodle and research instruments in the form of test questions were validated by the content of the expert team. This content validation was carried out to assess the suitability of Moodle with students' cognitive levels and the school curriculum and also to assess the suitability of the question grids with cognitive test items on mathematics and physics material.Cognitive learning outcomes tests were carried out 3 times, namely, on each sub-concept on the concept. In this study, the data analysis technique used is quantitative data analysis techniques. Processing and data analysis in this study was carried out in the form of calculating the N-gain score of the pretest and posttest scores of students in the cognitive aspect of the experimental class. The data obtained are then described in the form of tables, graphs, calculation of ranges, minimum scores, maximum scores of mean (mean), standard deviation, $\mathrm{N}$-gain and others in each class of mathematics and physics experiments. No normality test is carried out, homogeneity and hypothesis testing in this study because this study was conducted to obtain preliminary data in order to get a picture of student learning outcomes using Moodle, namely whether there is an increase in student cognitive learning outcomes before and after learning with Moodle. In addition, data on the validation results of Moodle and test questions are also not presented because this study aims to determine whether there is an increase in learning outcomes through the use of Moodle-based Learning Management System (LMS).

\section{Results and Discussions}

Data on students 'initial abilities were obtained from the students' pretest scores for each meeting. In this study, each student had three pretest scores from three meetings on mathematics and physics, as well as for the posttest and Ngain scores obtained. The average score can be seen in table 1 below which is descriptive statistical data of the average score of the three pretest and posttest times of each meeting in mathematics and physics learning activities with Moodle.

Table 1. Descriptive statistics of the average pretest, posttest and $N$ gain scores of students at learning mathematics and physics

\begin{tabular}{ccccccc}
\hline \multirow{2}{*}{ Subjects } & $\begin{array}{c}\text { Descriptive } \\
\text { statistics }\end{array}$ & $\mathrm{N}$ & Minimum & Maximum & Average (mean) & St. deviation \\
\hline \multirow{3}{*}{ Mathematics } & Pretest & 35 & 23 & 63 & 42.95 & 8.7 \\
\cline { 2 - 7 } & Postest & 35 & 57 & 97 & 76.48 & 9.39 \\
\cline { 2 - 7 } Physics & \% Ngain & 35 & 28 & 93 & 60 & 0.13 \\
\cline { 2 - 7 } & Pretest & 36 & 23 & 63 & 42.04 & 8.56 \\
\cline { 2 - 7 } & Postest & 36 & 50 & 87 & 67.31 & 8.79 \\
\hline
\end{tabular}

The results of Table 1 showed that there is an increase in the average score of students' cognitive learning outcomes in mathematics and physics. In addition, the minimum and maximum average scores have also increased. This is because based on interviews with students, students consider learning with Moodle easier to understand because the delivery of material is more systemic. Students can access the material they want to learn in an order that is tailored to the stages of learning activities. Assignment collection is also easier because it is provided in Moodle and students can see the results obtained at each meeting. In mathematics, students obtain a number of materials at each meeting in various forms of teaching media, some in the form of text, videos and simulations. In addition, there are many examples of questions in each sub-chapter of the material discussed which makes it easier for students to understand the material. Time is not an obstacle in the implementation of learning because students can access the material at any time, so that students can absorb the material according to their level of ability to understand the material. Learning with Moodle is very interesting for students studying mathematics material.

In physics subjects, students also consider that the material presented is easier to understand, which can be seen from the increase in student learning outcomes at each meeting. But when the material being taught is abstract and mathematical calculations are more complicated, students have difficulty solving it because students cannot understand the material presented. Students need more time to understand the material 
even though the material is presented in multimedia form, even though there are students who state that the material presented can be understood well if students really understand, follow and work on each step of completing the assignment given according to the sample questions. Students do not have difficulty completing tasks that involve simple mathematical calculations or questions that measure understanding of the concept of the material but students have difficulty completing tasks that require the ability to analyze or reason. Students need more detailed explanations and directions when solving questions that require analysis due to the level of students' ability to understand a variety of materials that can usually be solved through group work in classroom learning activities, where students easily do questions and answers with friends and teachers. Differences in cognitive learning outcomes in each of these subjects can be seen in Figure 1 below. Students need more detailed explanations and directions when solving questions that require analysis due to the level of students' ability to understand a variety of materials that can usually be solved through group work in classroom learning activities, where students easily do questions and answers with friends and teachers. Differences in cognitive learning outcomes in each of these subjects can be seen in Figure 1 below. Students need more detailed explanations and directions when solving questions that require analysis due to the level of students' ability to understand a variety of materials that can usually be solved through group work in classroom learning activities, where students easily do questions and answers with friends and teachers. Differences in cognitive learning outcomes in each of these subjects can be seen in the Figure 1.

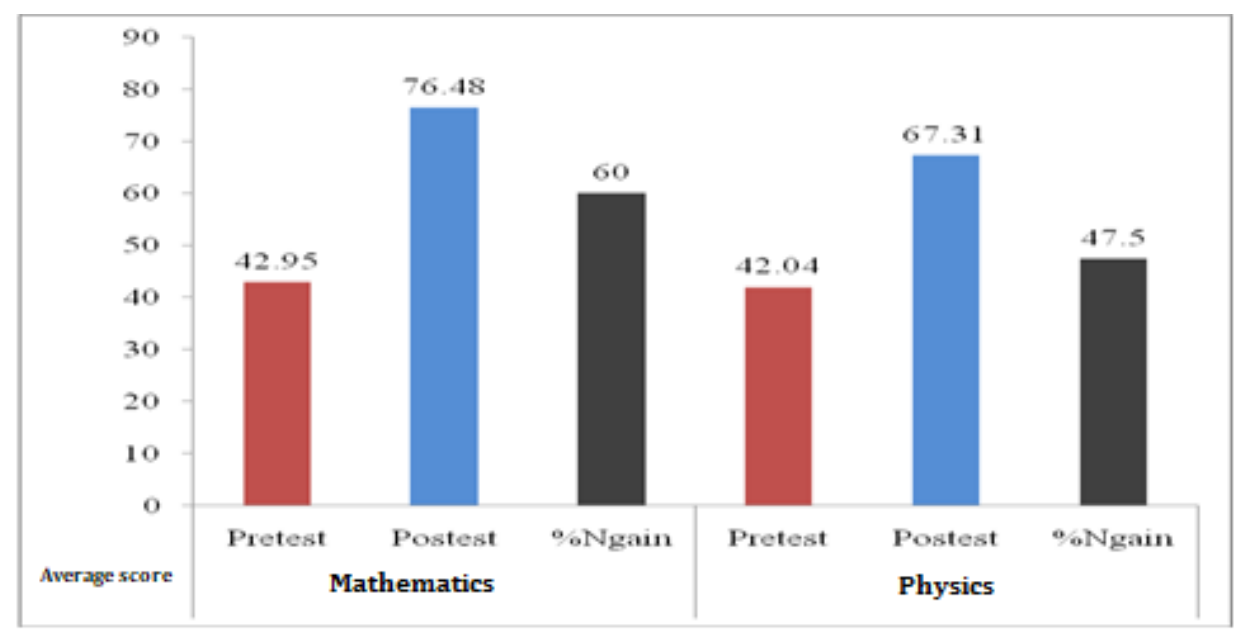

Figure 1. Diagram of the average score of the pretest, posttest, $\% \mathrm{~N}$-gain on the subjects mathematics and physics

Figure 1 is a graph obtained from statistical descriptive data of cognitive learning outcomes shown in table 1.Based on Figure 1, it can be seen more clearly that the cognitive learning outcomes of students in these two subjects, namely the cognitive learning outcomes of students in mathematics subjects are higher. on the pretest and posttest compared with cognitive learning outcomes in physics subjects. The\% score of Ngain is also greater in mathematics when compared to the\% score of physics subjects whose learning also uses Moodle. Many factors influence it, one of which is such as the data obtained from interviews with students who take lessons with Moodle for these two subjects. Moodle in learning activities. Even though this application is simple, lightweight, efficient because it uses simple technology but requires skills from teachers/lecturers/educators to be able to make good use of existing features so that they can be used effectively in learning activities. The problem in using Moodle is also not only an obstacle for educators but also an obstacle for students, especially students who are not familiar with the use of information and communication technology to access Moodle. Students need to familiarize themselves with the learning process with Moodle. In addition, students basically have various skill levels in accessing Moodle and of course this will affect their learning outcomes.

In this study, the success of student learning outcomes in terms of the average posttest score on these subjects. The expected success is at least $85 \%$ of students who take part in the learning process to get an average score above the minimum completeness criteria (KKM). The percentage of students who achieve the completeness criteria in mathematics and physics can be determined by looking at the results shown in Table 2 below which shows the frequency distribution of the average posttest score in each subject, namely in mathematics and physics, the determination of which is to add the percentage of students in the data interval class is greater than or equal to the KKM. 
Table 2. The distribution of the average frequency of the posttest scores in mathematics learning and physics

Postest Average Frequency Distribution

\begin{tabular}{cccccc}
\hline & Mathematics & & \multicolumn{3}{c}{ Physics } \\
\hline Interval Class & $\mathrm{F}$ & Percentage & Interval Class & $\mathrm{F}$ & Percentage \\
\hline $57-63$ & 3 & $9 \%$ & $50-56$ & 3 & $8 \%$ \\
\hline $64-70$ & 7 & $20 \%$ & $57-63$ & 9 & $25 \%$ \\
\hline $71-77$ & 12 & $34 \%$ & $64-70$ & 13 & $36 \%$ \\
\hline $78-84$ & 7 & $20 \%$ & $71-77$ & 8 & $22 \%$ \\
\hline $85-91$ & 4 & $11 \%$ & $78-84$ & 2 & $6 \%$ \\
\hline $92-98$ & 2 & $6 \%$ & $85-91$ & 1 & $3 \%$ \\
\hline & 35 & $100 \%$ & & 36 & $100 \%$ \\
\hline
\end{tabular}

Based on the results of the calculations in Table 2 above, it is found that the percentage of students who achieve the minimum completeness criteria in mathematics is $91 \%$ and in physics is $67 \%$. From the calculation, it can be seen that the mathematics class has been successful, meaning that student learning outcomes can meet the complete learning concept with the desired standard. The physics class has not yet achieved completeness because it has not achieved class success, namely as many as $85 \%$ of students have reached the completeness criteria because only $67 \%$ of students have reached the completeness criteria

This is based on the previous explanation that learning physics is not enough with understanding the concept, but must be followed by experiments and practices in the laboratory. Physics learning, if taught with the Moodle-based Learning Management System (LMS), can only improve learning outcomes up to the $\mathrm{C} 1$ and $\mathrm{C} 2$ cognitive levels, namely the knowledge and understanding of Babussalam SMKS students. As for other cognitive levels, the use or utilization of various multimedia integrated in Moodle must be increased. Moodle LMS for physics subjects that have been developed has not integrated systematic scientific-based learning multimedia so that the increase in student learning outcomes is still in the medium category compared to mathematics learning which is in the high category.

This study has two classes which are used as research samples, namely class XI1 as the mathematics class and class XI2 as the physics class. Both classes were given treatment by applying the learning process using the Moodle-based Learning Management System (LMS). The use of different classes is intended for the effectiveness of the implementation of learning time with the consideration that the two classes basically have the same or almost the same level of ability based on the pretest results, namely based on the pretest results which are supported by the pretest average score difference test between the mathematics class and the physics class. shows that there is no significant difference in the initial ability of the two classes. Differences in cognitive learning outcomes between students are influenced by various factors, including learning materials that are not suitable if taught with a remote system. Therefore teachers must selectively choose to present suitable learning for certain subjects so that the learning objectives set are achieved, especially during the current pandemic. The recent outbreak of COVID-19 has led to the application of digital-based learning ore-learningvery useful for protecting students from the spread of the COVID-19 virus. Moreover, the government has appealed to the public to be able to do activities at home as an effortphysical distancing or maintain physical distance to suppress the spread of the virus.

However, unlike the name which sounds sophisticated, implementation e-learning or online learning also has the following advantages and disadvantages: Excess application e-learning includes: 1. Easily accessible, 2. The cost is more affordable, 3. Study time is flexible, 4. Broad insight. As for the drawbacks application of e-learning: 1. Limited internet access, 2. Less interaction with teachers, 3 . Understanding of the material, 4. Lack of Supervision in Learning (Hadisi \& Wa, 2015).

Learning Management System(LMS) is a software application used by educators, both universities or colleges and schools as an internet-based online learning medium (Arifah R, et al, 2016). Meanwhile, Moodle is one of the open source software of e-learning that can be applied in the learning process in the form of an open source web whose use does not require fees or is free (Ariyanti in Muazizah et al, 2016). In addition, the Moodle-based LMS can be modified as needed. One of the advantages for educators in making LMSbased online learning is convenience (Herayanti et al, 2017). In addition to convenience, Moodle is also an effective medium because it provides learning facilities because it is equipped with important learning support features such as assignments, quizzes, chat, collaboration, as well as the main feature that can upload various formats of learning material and is easier to understand because the information presented is not only in the form of writing but also images (Sampurno et al. 2015). Various sources can be attached as 
learning materials. Written manuscripts written from a Microsoft word processing application, presentation material from Microsoft Power Point, Flash animation, virtual experiments such as PhET and even material in audio and video formats can be attached as learning materials, so that it can make it easier for students to carry out the inquiry process such as, looking for information, conducting experiments, collecting data, and practicing to solve questions on the link that has been linked to the Moodle application (Herayanti, 2015).

Moodleh as a number of benefits including overcoming the limited frequency of face-to-face meetings between students and lecturers. Moodle (Modular Object Oriented Dynamic Learning Environment) which means a dynamic learning place using an object-oriented model or a dynamic web-based educational environment package (Herayanti et al., 2015). But even so, in practice it is not always in line with expectations because the skills of teachers or lecturers in utilizing the Learning Management System greatly determine the success of learning, especially in exact learning such as physics, chemistry and biology which must implement the scientific process to achieve the learning completeness criteria as set out. Other than that, The achievement of learning completeness criteria must also be supported by the potential possessed by students, namely students must be accustomed to using Moodle and have high motivation to participate in learning activities with Moodle. This fact is evidenced by the implementation of learning by utilizing the Moodle-based Learning Management System at Babussalam SMKS.

Learning mathematics and physics using the Moodle-based Learning Management System at Babussalam SMKS shows that learning using the Moodle-based Learning Management System (LMS) is not suitable if used in physics learning at Babussalam SMKS, this is because the Moodle developed has not integrated the scientific aspects in the process. physics learning. The implementation of learning based on the scientific approach is still an obstacle in face-to-face learning in class and of course it is also an obstacle to online learning because physics as a subject in the process of implementing learning activities cannot be separated from scientific activities.

Physics is the study of the interaction between energy and matter which is the basis of natural science. In learning physics, students are expected not only to master the concepts of physics in theory but also to be able to use scientific methods to prove the physics concepts obtained from the theory (Hermansyah et al., 2015). Therefore, the developed Moodle must integrate scientific aspects because physics is not only about mastering the concept in theory but must be done with a scientific approach so that the learning outcomes obtained can last a long time. However, the development of Moodle which integrates scientific aspects is also not easy because it requires multimedia utilization skills for the developer.

Moodle which was developed with the integration of the scientific approach shows an increase in learning outcomes that is better than Moodle without integrating the scientific approach as shown in the research of Muazizah et al. (2016), namely $91.67 \%$ of students achieved learning completeness. The use of Moodle-based e-learning with the Guided Inquiry approach is effective for learning outcomes. Learning using Moodle-based e-learning with the Guided Inquiry approach increases student curiosity so that students are more active in participating in learning. In addition, during the learning process students experience a Guided Inquiry process which makes students find the concept of the material being studied so that students master the concept better.

\section{Conclusions}

Based on the results of research data analysis and discussion, the percentage of the number of students who have met the completeness criteria is to find out whether student learning outcomes have met the expected criteria. The results of this study showed that learning completeness in the physics class was achieved at $67 \%$, while in the mathematics class it was $91 \%$. From the calculation, it can be seen that the mathematics class has been successful, meaning that student learning outcomes can meet the complete learning concept with the desired standard. Physics class has not achieved completeness because it has not achieved class success by $85 \%$, which means that student learning outcomes cannot fulfill the complete learning concept with the desired standards. In addition, it can be seen that the student learning outcomes in the mathematics class are better than the physics class. This is based on the data that the N-gain average of cognitive learning outcomes in mathematics class is higher than the $\mathrm{N}$-gain average of physics class. This condition is caused by learning physics itself, learning physics is not enough with understanding concepts, but must be followed by experiments and practices in the laboratory. Physics learning, if taught with a Moodle-based Learning Management System (LMS), has not been able to integrate multimedia learning that can improve psychomotor aspects to improve understanding of deeper physics concepts that support improved student learning outcomes. 


\section{Acknowledgement}

The author would like to thank LPPM Malikussaleh University for its financial support in this research and the school of SMKS Babussalam North Aceh for their support in participating in this scientific activity. The authors also thank the experts for their useful discussions.

\section{References}

Abda, M. I., Muliana, M., \& Fonna, M. (2020). Implementation of Somatic, Auditory, Visual and Intellectual (SAVI) Approaches to Improve Student's Mathematics Communication Skills in SMK Negeri 1 Nisam. International Journal for Educational and Vocational Studies, 2(6).

Adzharuddin, NA \& Ling. LH 2013. Learning Management System (LMS) among University Student: Does it Work? f. International Journal of Education, e-Business, e-Management and Learning. 3 (3): 248. (Online). (https://www.researchgate.net/publication, accessed November 20, 2020)

Albariki, A. Y., Prasetyo, K., \& Sunarto, S. (2020). The Effects of Learning Media Lectora Inspire of Indonesian Plurality Material on the Results of Learning Social Studies Affective Tolerance at the SMPN 1 Krembung. International Journal for Educational and Vocational Studies, 2(4).

Ariesta, Freddy Widya, Suwarno \& Olifia Rombot. 2019. Enhancing science learning outcomes through Moodle-based e-learning in elementary schools (Online). https://www.semanticscholar.org/paper, accessed November 27, 2020). 2 (10): 2183-2187)

Arifah R, Lidani, Fauzi Bakri, \& Dewi Muliyati. 2016. E-Learning Tool Development Using Chamilo for Basic Physics Courses II. Proceedings of SNIPS 21-22 JULY 2016, p. 492. ISBN: 978-602-61045-0-2

Febrianto, Priyono Tri. (2020). Implementation of online learning during the covid-19 pandemic on Madura islan, Indonesia. (On line). (https://doi.org/10.26803/ijlter.19, accessed November 25, 2020). 19 (8): 233-254

Gunawan. 2015. ICT-based science learning model. Mataram. FKIP, University of Mataram.

Gunawan. G, H Sahidun, S Susilawati, A Harjono \& L Herayanti. 2019. Learning Management System with Moodle to Enhance Creativity of Candidate Physics Teacher. (Online). (https://iopscience.iop.org/article/10.1088/17426596/1417/1/08, accessed 27 November 2020)

Hadisi, La \& Wa Muna. 2015. Management of Information Technology in Creating Learning Innovation Models (E-Learning). Al-Ta'dib Journal. Vol. 8 No. 1. Pages 117-138

Herayanti, L. Habibi. 2015. Problem-Based Learning Model Assisted by Computer Simulation to Improve Critical Thinking Skills of Prospective Physics Teacher. Journal of Physics and Technology Education, 1 (1), 61-66.

Herayanti, L., Fuaddunnazmi, M., \& Habibi, H. 2015. Development of Moodle-Based Learning Media in Basic Physics Courses. Journal of Physics and Technology Education, 1 (3), 205-209.

Herayanti, L., Habibi, H., \& Fuaddunazmi, M. 2017. Development of Moodle-Based Learning Media in Basic Physics Subjects. Journal of Cakrawala Pendidikan, 36 (2).

Hermansyah, H., Gunawan, G., \& Herayanti, L. 2015. The Effect of Virtual Laboratory Use on Students' Mastery of Concepts and Creative Thinking Ability on Vibration and Wave Material. Journal of Physics and Technology Education, 1 (2), 97- 102.

Irfan, Muhammad, Betty Kusumaningrum, Yuyun Yulia \& Sri Adj Widodo. 2020. (Online). (https://doi.org/10.22460/infinity.v9i2.p147-158, accessed November 26, 2020.9 (2): 147-158.

Karlina, Bella. 2015. The Effect of Facility Management on the Quality of Education and Training Services at the Center for Development and Empowerment of Educators and Education Personnel in the Field of Mechanical and Industrial Engineering (Pppptk Bmti). Bandung: UPI.

Kusuma, J. W., \& Hamidah, H. (2021). Online Learning: Student's Perception off Lecturer's Competence and its Influence on Achievement Motivation. International Journal for Educational and Vocational Studies, $3(1), 37-43$. 
Mada, R. D., \& Anharudin, A. (2019). How Online Learning Evaluation (Kahoot) Affecting Students' Achievement and Motivation (Case Study on it Students). International Journal for Educational and Vocational Studies, 1(5), 422-427.

Marhami, M., Fonna, M., Mursalin, M., \& Nuraina, N. (2020). The Effect of Video Conference Assisted Online Learning on Students' Mathematical Problem Solving Ability during the Covid-19 Pandemic. International Journal for Educational and Vocational Studies, 2(11).

Mauliza, M. (2020). Improving Students' Learning Result Using Numbered Heads Together Model. International Journal for Educational and Vocational Studies, 2(3).

Muazizah, Noor Malikhah, Sri Nurhayati, \& Edi Cahyono. 2016. The Effectiveness of Using Moodle-Based ELearning with Guided Inquiry Approach to Student Learning Outcomes. Journal of Chemical Education Innovation, Vol 10, No. 2, pages 1760-1768

Na'imah, NJ, Supartono and Wardani, S., 2015, Application of project-based learning assisted by e-learning to improve student learning outcomes, Journal of Chemical Education Innovation, Vol 9, No 2, Page 1933.

Nurulwati, N., Zulfahmi, Z., \& Susanna, S. (2020). The Effect of Discussion Learning on Cognitive Students' Ability in Teaching Learning Strategies. International Journal for Educational and Vocational Studies, 2(3).

Rohida, Leni. 2018. The Influence of the Industrial Revolution Era 4.0 on Human Resources. Journal of Indonesian Business Management.

Sampurno, PJ, Maulidiyah, R. \& Puspitaningrum, HZ 2015. Implementation of Curriculum 2013: MOODLE (Modular Object Oriented Dynamic Learning Environment) in Physics Learning through Student Worksheets on Optical Materials in SMA. Indonesian Education Journal, 19 (56), 54-58.

Sukmadinata, Nana Syaudih. 2020.Educational research methods. Bandung: Youth Rosdakarya (Beta Book).

Sugiyono. 2017. Quantitative, Qualitative, and R \& D Research Methods. Bandung: CV. Alfabeta.

Syauqi, Khusni, Sudji Munadi \& Mochamad Bruri Triyono. 2020. Students'perceptions toward vocational education on online learning during the covid-19 pandemic.

(On-line). (http://ijere.iaescore.com/index.php, accessed November 26, 2020). 9 (4): 881-886 